\title{
The status of English in the EU institutions after Brexit: A discursive analysis of selected press articles
}

\author{
ALBERT GUZIAK
}

\begin{abstract}
The aim of this article is to find out what the status of English, currently the primary working language within the EU institutions, might look like once the United Kingdom leaves the EU structures. To that end, this paper will analyse a selection of press articles. Although the manner in which the so-called Brexit will take place is still uncertain, a diverse range of opinions and prognostications on what will happen to English is being expressed publicly, taking into consideration many factors (political, sociological and purely linguistic) which may contribute to a possible scenario or scenarios. This article does not lay claim to submitting any firm or reliable vision of the future as none such exists elsewhere. This paper intends to analyze some discursive strategies employed by the authors of the articles to place the discussed subject into a discursive framework by using tools of critical discourse analysis which mainly focus on the relation of power and language.
\end{abstract}




\title{
Keywords
}

Brexit, critical discourse analysis, English, European Union, media discourse

\section{Status języka angielskiego $\mathrm{w}$ instytucjach UE po brexicie - analiza dyskursu wybranych artykułów prasowych}

\begin{abstract}
Abstrakt
Celem niniejszego artykułu jest próba określenia, na przykładzie wybranych artykułów prasowych, jak może wyglądać status języka angielskiego jako obecnego podstawowego języka roboczego w instytucjach UE, po tym jak Wielka Brytania opuści struktury Unii Europejskiej. Pomimo faktu, że sposób oraz warunki wyjścia Zjednoczonego Królestwa $z$ Unii Europejskiej, tzw. brexitu - nie zostały jeszcze ustalone, w opinii publicznej wciąż pojawiaja się liczne komentarze oraz prognozy dotyczące tego, jak będzie wyglądał status języka angielskiego w instytucjach unijnych w nowych „po-brexitowych” realiach, biorac pod uwage wielorakie czynniki - natury politycznej, socjologicznej i czysto językowej, które mogą umożliwić nakreślenie możliwych scena-riuszy. Artykuł nie prezentuje jednej pewnej wersji dotyczacej pozycji i statusu języka angielskiego (nie jest też możliwe jednoznaczne jej określenie), skupia się na przedstawieniu i analizie strategii dyskursywnych, jakimi autorzy wybranych artykułów prasowych mogli się posłużyć, w celu umieszczenia omawianego tematu w określonych ramach dyskursywnych. Do zbadania owych strategii wykorzystano narzędzia krytycznej analizy dyskursu, która w głównej mierze ukazuje relację władzy i języka.
\end{abstract}

\section{Słowa kluczowe}

Brexit, dyskurs medialny, język angielski, krytyczna analiza dyskursy, Unia Europejska 


\section{Premises of the present discursive analysis}

The invocation of Article 50 of the Treaty on European Union by the UK's government in 2017 (commonly known as Brexit) entailed an ongoing discussion on whether English would maintain its predominance as the primary working language utilized by the EU institutional apparatus. There have been many debates, media articles, political comments or statements on that matter, none of them giving credit to one particular scenario; the complexity of this relation between power and language is accompanied by the fact that even the manner in which Brexit will be implemented is as yet undetermined. Although this issue is creating a political whirlwind and uncertainty on both sides of the English Channel, one indisputable point is that English is by no means a lingua franca of our times and this must be taken into ac-count even if the UK finally leaves the EU after the transition period. As mentioned before, the consequences of Brexit for the English language are to be considered at many levels of common public communication. By the example of the chosen press articles, I intend to shed some light on the continuing public debate by using tools of critical discourse analysis which should demonstrate linguistic strategies to confirm different hypotheses that the authors of the chosen material have proposed.

\section{Linguistic landscape within the EU institutions}

Linguistic diversity is one of the foundations of the EU that comes to the fore in Europe each and every day. Languages constitute both an essential part of European identity and the most direct expression of culture. In the EU, constructed on the motto "United in diversity", the ability to communicate in several different languages is an essential advantage for common people, organizations and businesses. Languages are also a cornerstone for respecting cultural and linguistic diversity in the EU. Respect for a linguistic mosaic is a fundamental value of the EU, 
as is esteem for the individual person and an openness towards other cultures. This is incorporated into the preamble to the Treaty on European Union, as can be read in the following: "drawing in-spiration from the cultural, religious and humanist inheritance of Europe and confirming the attachment to the principles of liberty, democracy and respect for human rights". This approach has no precedent, either among multilingual states or even in international organizations. The principle is anchored in the EU's Charter of Fundamental Rights - as an EU national, every EU citizen has the right to use any of the 24 official languages to contact the EU institutions, and the institutions are obliged to reply in the same language, pursuant to Article 41(2)(1): "Every person may write to the institutions of the Union in one of the languages of the Treaties and must have an answer in the same language". EU law and other legislative texts are published in all official languages, except Irish, due to resource-related reasons (only regulations adopted by both the Council of the European Union and the European Parliament are currently translated into Irish). Meetings of the European Council and the Council of the European Union are interpreted into all official languages. Members of the European Parliament benefit from the right to use any official language when making speeches in Parliament. The term official languages, due to the nature of a legal aspect, also requires a legal clarification; the first relevant regulation, dating from 1958, determining the languages to be used by the former European Economic Community, has been amended following subsequent accessions to the EU, and defines the Union's official languages, together with Article 55(1) TEU (Treaty on European Union) which states:

This Treaty, drawn up in a single original in the Bulgarian, Czech, Danish, Dutch, English, Estonian, Finnish, French, German, Greek, Hungarian, Irish, Italian, Latvian, Lithuanian, Maltese, Polish, Portuguese, Romanian, Slovak, Slovenian, Spanish and Swedish languages, the texts in each of these languages being equally authentic, shall be deposited in the archives of the Govern- 
ment of the Italian Republic, which will transmit a certified copy to each of the governments of the other signatory States.

This legal article is a prerequisite for all official legal documents issued by the EU institutions addressing all EU member states, confirmed in the legal spirit of related regulations, corroborated by the relevant values underlying the EU and grounded in everyday practice. Every citizen of the EU has the right to write to any of the institutions or bodies of the EU in one of these languages and to receive an answer in the same language. However, considering the everyday practice of using languages as a working tool within the EU institutions only three are classed as working languages: English, French and German. Of those three, English is, without doubt, predominant and its elevated position (in comparison with French e.g.) has been continually growing over the past 25 years. This appears to be the result of new countries who brought into the EU a large wave of speakers whose first foreign language was English, according to the article: As Britain leaves, English on rise in EU - to French horror, appeared on May 7th 2018:

English has also long been in ascendance as the EU's main working language after the last wave of enlargement from 2004 which provided officials and diplomats from Central and Eastern European countries who had studied the language of Shakespeare, but not of Molière's. The use of EU English - sometimes called Globish for its non-native eccentricities - has become so widespread that several institutions have made behind-the-scenes efforts to streamline costs or improve their efficiency by either prioritizing an Englishonly format or adding English to meetings where French was once used exclusively.

\section{Predominance of English as a global language}

In order to better understand what might ensue in the balance of linguistic powers from the UK's leaving the EU, one must first have a closer look at the factors that contributed (or are 
contributing) to the superior position of English as the first working language of the EU institutional apparatus. According to Crystal (2003), the general developing dominance of English was a result of two factors: the expansion of British colonial power, which peaked towards the end of the nineteenth century, and the emergence of the United States as the leading economic power of the twentieth century. This shift of political power took place to the detriment of other major European languages such as French or German. Political dominance, however, is ineffective for the widespread use of a particular language if that language is not accompanied by an attractive culture that could be embraced or followed by ordinary people. Cultural power seems thus to be at least equal in importance to political power affirming the latter. But as has been seen, English is the dominating linguistic force in the EU right now, and this is not just true of languages used within the institutions. As the Williams (2016: 68) say in their work "the emerging de facto process within Europe involves accepting English as the universal lingua franca". This brings us to the theories surrounding English as the most prominent international language in Europe in general. But how did English reach this level of dominance in the supranational European scene?

Phillipson (2003) distinguishes two main aspects that he considers to have contributed to the rise of English: the structural aspect and the ideological aspect. Structural aspects involve such factors as internet usage, the investment in teaching English in many countries around the world, attractive exchange programs of English-speaking countries for students, and the mobility of labor leading to a preference for an already dominant language. Ideological aspects, on the other hand, include the different ways that language policy issues are understood in different countries, and the levels of awareness of language policy issues. It is obvious that English has assumed the role of the leading actor on the European linguistic scene. To strongly underline this statement, one must not ignore the purely linguistic qualities, advantages and intrinsic features of the English 
language which helped to accelerate its European or world-wide diffusion among non-native speakers of English. First of all, English is a very flexible language. One example of this is the ability of conversion i.e. using the same word as both a noun and a verb (drink, fight, silence etc.). English grammar is generally considered and felt to be simpler than that of most other common languages. It dispenses entirely with noun genders (no dithering about French's le plume and la plume 'feather' or 'pen', or about el mano and la mano 'hand'), and often dispenses with the article completely (It is time to go to bed). The distinction between familiar and formal addresses was abandoned centuries ago. The single English word you has seven distinct choices in German: $d u$, dich, dir, Sie, Ihnen, Ihr etc. Case forms for nouns are almost non-existent (with the exception of some personal pronouns like I/me/mine, he/him/his etc.), as compared to Finnish, for example, which has fifteen forms for every noun, or Russian which has twelve. In German, each verb has sixteen different forms, while English retains only five at most (ride, rides, rode, riding, ridden) and often only requires 3 (hit, hits, hitting).

On the other hand, English possesses some inherent traits which might not appeal to non-natives, such as pronunciation that seems to be relatively simple but has more than its fair share of apparently random spellings, silent letters and phonetic inconsistencies. Examples include the pronunciation of the ou in thou, though, thought, through, thorough, tough, plough and hiccough, or the ea in head, heard, bean, beau and beauty. Nevertheless, as a working language and vehicular language of communication it offers valuable traits; English is generally reasonably concise compared to many other languages, as can be seen in the length of translations (a notable exception being Hebrew, whose translations are usually shorter than their English equivalents by up to a third). English is, additionally, less prone to misinterpretations because of social nuances than, for example, Japanese. The non-appearance of coding which distinguishes social variations (a feature peculiar to a number of different 
languages recognizing a difference between formal/informal verbal structures and strongly accentuated feminine and masculine noun forms) may cause English to appear progressive and liberal with the result that its users do not fear that they are committing any linguistic faux pas. Taking into account the above-mentioned factors and the irrelevance of the richness of varieties of English (including within the EU institutions), the language of Shakespeare occupies a prominent position among other global languages as the universal lingua franca. This fact also pertains well to its present dominance in the EU institutions. Will this supremacy of English be shaken after Brexit?

\section{Materials and methodological foundation}

In order to attempt to answer the question posed in the preceding chapter, I have chosen three different press articles which were issued online within the last two years and these are: "EU has no plans to downgrade use of English after Brexit appeared" (The Guardian, 2018), "As Britain leaves, English on rise in EU - to French horror" (Politico, 2018) and "The fate of English in the EU after Brexit: Expected and unexpected twists" (online edition of VOX CEPR Policy Portal). The most relevant method through which I will execute this analysis is critical discourse analysis (CDA) which traditionally focuses on power relations and on how they are expressed and utilized through discourse, in this case via the chosen online press articles. In my view, this method will adequately cover the submitted thesis of the position of English since this aspect primarily results from the power relations within the EU institutions. The CDA is the core of this research and discourses are seen as central social practices wherein interdiscursivity, material conditions, and other social practices in discursive social analysis are emphasized. Furthermore, CDA is equipped with tools to look at comparatively more abstract aspects of the text, such as implications, intertextuality and context etc. I will apply Norman Fairclough's view of CDA, being that "discourses should ideally be analyzed 
simultaneously at three levels: text (micro-level textual elements), discursive practice (production and interpretation of texts), and social practice (situational and institutional context)" (Melckersson 2018). Following Fairclough's perspective, CDA is as much a theory as it is a method, and it has to be connected with a specific context to produce meaningful interpretations. A specific interpretation is then related to the term legitimation which refers to a broader social context. The process of legitimation is that through which something becomes legitimate, in other words, gains legitimacy (Fairclough 2010). The use of semiotic practices, language, and more specifically discourses, within some social and political framework of beliefs, norms, and values plays an important role in constructing legitimacy.

According to Fairclough and Wodak, CDA sees discourse language use in speech and writing - as a form of "social practice". Describing discourse as social practice implies a dialectical relationship between a particular discursive event and the situation(s), institution(s) and social structure(s), which frame it: The discursive event is shaped by these, but it also shapes them (Norman/ Ruth in van Dijk 1997). Within this framework, I am going to employ an analysis of the legitimation strategies proposed in the context of CDA by van Leeuwen and Wodak. The four legitimation strategies are as follows: rationalization provides the rationale, establishes recurring rationalities (e.g. by referring to experts, and proven statistics), authorization authorizes claims, establishes recurring authorizations and authorities (e.g. by referring to authorities or those in recognized positions of authority), narrativization - provides a narrative structure to concretize and dramatize, establishes recurring narrative and drama structures involving references (e.g. by referring to exaggerations), moralization - provides the moral and ideological basis, establishes recurring moralities and ideologies (e.g. by referring to some values, norms and emotions) (Melckersson 2018: 12). 


\section{Discursive analysis of the selected press articles}

\section{1. "EU has no plans to downgrade use of English after Brexit"}

The article proposes an explicit and unequivocal hypothesis, according to which, it is not the EU's intention to downplay the usage of English as a working language once the UK leaves its structures. As one will deduce from the first passage of the text, the European Commission, or more precisely a communique issued by this executive body, said: "Buried in the small print of the European commission's proposed budget for 2021-27 is confirmation that it has no intention to reduce the use of English in its meetings or documents". As can be seen here, the author specifically used the authorization strategy and so this seems to be the intention of the text - to maintain an objective perspective by referring to the officials' statement. This aim is furthered by the second strategy of rationalization, used in the article. References to statistics about the number of native English speakers living in the EU are found there: "When the UK leaves the EU in 2019, only $1 \%$ of the EU population - in Ireland and Malta - will be living in countries where English is an official language", are used, as well as information to prove something about the popularity of English within the EU institutions:

English has been used more widely used than French since Sweden, Finland and Austria joined the EU in 1995, bringing in more speakers of English as a second language. The dominance of English became entrenched when central and eastern European countries joined in the mid-2000.

In this article, the narrativization strategy can also be seen, for example, in the following fragment: "France is keen to restore the pre-eminence of its language, but is fighting a constant battle. Its EU ambassador walked out of a meeting last week when officials decided to use an English-only translation of the budget 
proposal". This ironic and slightly mocking echo in the text is presumably explicable by the fact that the author and the magazine are both British and that it accurately reflects the permanent battle for supremacy between the English and the French, mostly re-initiated and conducted by the French.

\section{2. "As Britain leaves, English on rise in EU - to French horror"}

Here is a sort of dramatization/exaggeration in the title of this article, particularly in its second part. This, according to the previously discussed strategies, would represent the narrativization of the content. This strategy, how-ever, only rarely appears again in the whole text; referring to a diplomatic incident from 2018 during which France's EU Ambassador ostentatiously left an official meeting of the Council after its decision to use only the English translation:

Late last month, France's EU Ambassador Philippe Léglise-Costa walked out of a diplomatic meeting after the Council decided to use only English-language translation in a new working group on the EU's long-term budget (ignoring his demand for arrangements for other languages).

This passage concretizes and dramatizes the whole echo of this article. The two main strategies the author operates with are rationalization and authorization. The text makes several references to people or officials in established positions such as: "It is a lost fight, said Alain Lamassoure, a former minister and senior French MEP from the conservative European People's Party. "The French language has occupied a dominant position but I wouldn't know how to maintain that". The first part is equally an example of narrativization strategy. The authorization strategy is further found in: "Last year, Mario Monti, the former Italian prime minister and European commissioner, said English should become the EU's main official language once the 
U.K. leaves the bloc". On the other hand, the author brings up specific statistics which tend to prove that the situation of French as a second working language might shift to the detriment of English, as can be read in the following passages: "At least 80 percent of Commission officials speak French as a first, second or third language. There are 141,725 pages translated into French, and 422 out of 552 interpreters have had French in their language offer for years", reassured by evoking an authority (authorization strategy): "since the beginning of the Juncker's mandate, the use of French has been invigorated in internal meetings and public speeches, in particular, French is present in almost all meetings of the Commission". Moralization strategy, the last of the four, appears in the text by referring to value and emotion-based attitudes towards the usage of French, represented by France's current president, Emmanuel Macron:

This domination of English is not inevitable, Macron told French officials at a re-cent speech at the Institut de France in Paris. It is up to us to simply get some rules back in place [...] occupy some places again, he said. English is not destined to be the only foreign language Europeans speak, he added.

The author of this article frames its text in the context of EU institutional intricacies between higher officials and state dignitaries, putting its stress on their statements and public utterances, accompanied by some statistics and data. The resonance is rather neutral and void of emotional bias towards any of the parties in the linguistic contention, merely assuming, based on proofs, that English might keep or even enhance its predominance in EU institutions. 


\section{3. "The fate of English in the EU after Brexit: Expected and unexpected twists"}

The authors of this article, which appeared in 2018 on the website of VOX CEPR Policy Portal, argue (while preserving a tone of neutrality) that the status of English after Brexit is uncertain. This does not actually contravene any sound-minded impression of the mechanism of EU institutions and their internal intricacies and 'diplomatic tug of war', it just concludes that any-thing could happen in the matter of English. The wording in the heading of the article shows some dramatization in the message and creates a vision of a film-like scenario. The strategy used is a good example of narrativization. This strategy, however, should signal that the article will present creative and visionary scenarios reminiscent of an action movie or an historical drama. In fact, the possible outcomes of Brexit and specifically its ramifications for the usage of English are based on strict data and statistics, thus utilizing the rationalization strategy as in Figure 1.

\begin{tabular}{lcccccc}
\hline & \multicolumn{2}{c}{ Method 1 } & \multicolumn{2}{c}{ Method 2 } & \multicolumn{2}{c}{ Method 3 } \\
\hline & Before & After & Before & After & Before & After \\
\hline English & 37 & 28 & 13 & 1 & 25 & 15 \\
\hline German & 25 & 28 & 18 & 20 & 21 & 24 \\
\hline French & 20 & 21 & 13 & 15 & 16 & 18 \\
\hline Italian & 13 & 15 & 12 & 13 & 13 & 14 \\
\hline Spanish & 11 & 12 & 8 & 9 & 10 & 11 \\
\hline Polish & 8 & 9 & 8 & 9 & 8 & 9 \\
\hline
\end{tabular}

\section{Figure 1}

Percentage of speakers in the European Union before and after Brexit for the six most-spoken languages in the European Union (The Fate of English in the EU after Brexit 2020) 
Figure 1 is based on data gathered from a study conducted by the Special Eurobarometer Survey and commissioned by the European Commission. It shows the total number of speakers of the 6 most spoken languages in terms of population number, regardless of whether these speakers are native, proficient or just speakers of those languages. This table, accompanied by the methodological clarification, composes the core of the presumptions and theories on the usage of English after Brexit, which were drawn by the authors of this article. This data leads them to conclude that English might lose its dominance once the UK leaves the EU. Apart from the hefty statistical foundation, the article also makes reference to established norms or recurring emotions, like in the following:

In principle, there are two routes to sustain English as an official language of the EU: Ireland or Malta switches their official native language in the EU to English. This may create a national problem. Although most Irish and Maltese citizens speak English, how would they react to this 'unpatriotic' change?

The quote above deals with possible problematic consequences for the language identity of the two remaining English-speaking countries. The second emotional echo can be heard in the following fragment, illustrating the complexity of exercising power, here in terms of language, by the two "engines" of the EU: France and Germany: "It would be surprising if Germany (and Austria) or France (and French-speaking Belgians) were to support a status quo sustaining the current prevalence of English". The empirically or emotionally based and tainted assumptions are concluded with a reference to authority, in this case the Council of European Union which should eventually decide on the reshuffling of linguistic positions within the EU institutions:

The EU Council, which has to vote unanimously, would have to find extremely good arguments to convince countries to vote for the introduction of English in place of Irish by Ireland (or Maltese by 
Malta) - or to vote for English, if English ceased to be an official language in the $\mathrm{EU}$.

This article generally frames the problem of the status of English after Brexit in the context of strong statistical data on the usage of languages among EU citizens, values and norms (like in the cases of the Republic of Ireland and Malta) and institutional competency on that matter within the EU. As with the previous articles, this one also does not provide one definite future scenario.

\section{Conclusion}

In conclusion, we can only attempt to give ourselves an idea of what the position of English after Brexit might look like at the EU level; the ongoing discussion is to be placed into a wider scope and context of the role which English has been playing at the global level. From the elected textual material and the applied methodology, we could infer that the current domination of the English language within the EU institutions seems to be rather unchallenged and unthreatened. This conclusion is corroborated by the frequent references to public and official statements either made by key leaders of the EU or issued by its main institutions. Furthermore, some statistical and empirical data are evoked in the articles to underpin this thesis. Nevertheless, some tendencies of a political nature which aim at shaking the predominance of English within the EU, could not be, however, taken for granted as a larger Europe-wide phenomenon. As we learnt from the presented methodology of CDA, the relation of power and language is a dynamic construction, always inserted into a specific and updated socio-political context and the outcome is still in the distant future providing that the UK leaves the EU for good or bad. 


\section{References}

"As Britain leaves, English on rise in EU to French horror". Available at <https://www.poliico.eu/article/french-english-language-brexit -european-parliament-ecj-commission-eu-next-waterloo/)>. Accessed 10-20.03.2020.

Consolidated version of the Treaty on European Union. Available at $<$ https://eurlex.europa.eu/resource.html?uri=cellar:2bf140bf-a3f 8-4ab2-b506fd71826e6da6.0023.02/DOC_18format=PDF>. Accessed 10.03.2020.

Crystal, David (2003). English as a Global Language. Cambridge: Cambridge University Press.

Deneire, Marc (2017). "The British leave, but European Englishes remain". World Englishes 36/3 (Sept. 2017), DOI: 10.1111/ weng. 12267, 336-338.

EU has no plans to downgrade use of English after Brexit. Available at <https://www.theguardian.com/politics/2018/may/04/eu-hasno-plans-to-downgrade-use-of-english-after-brexit>. Accessed 1020.03.2020.

Fact sheets on the European Union. Available at $<$ https://www.europarl.europa.eu/factsheets/en/sheet/142/language-policy>. Accessed 10.03.2020.

Fairclough, Norman (2010). Critical discourse analysis: the critical study of language. Harlow: Longman

Fairclough, Norman, Ruth Wodak (1997). "Critical Discourse Analysis". In: Teo van Dijk (ed.). Discourse as Social Interaction. London: Sage Publications, 262.

Krippendorff, Klaus (2004). Content Analysis: An Introduction to Its Methodology. London: Sage Publications.

Language issues - English as a global language. Available at $<$ https://www.thehistoryofenglish.com/issues_global.html>. Accessed 14.03.2020.

Melckersson, Jennifer (2018). English in Europe post-Brexit: An analysis of the post-Brexit discourse surrounding English as a European lingua franca. Available at <http://lup.lub.lu.se/luur/download? func $=$ downloadFile\&recordOId $=8946164 \&$ fileOId $=8946167>$. Accessed 17.03.2020. 
Motschenbacher, Heiko (2013). New Perspectives on English as a European Lingua Franca. Amsterdam: John Benjamins Publishing Company.

Phillipson, Robert (2003). English-Only Europe? Challenging Language Policy. London: Routledge.

"The fate of English in the EU after Brexit: Expected and unexpected twists". Available at <https://voxeu.org/article/english-languageeu-after-brexit>. Accessed 14.03.2020.

Williams, Glyn, Gruffudd Williams (2016). "Language, hegemony and the European Union”. In: Re-examining 'Unity in Diversity'. Basingstoke: Palgrave Macmillan, 34.

\author{
Albert Guziak \\ ORCID iD: 0000-0001-8748-624X \\ Instytut Lingwistyki Stosowanej \\ Uniwersytet Warszawski \\ ul. Dobra 55 \\ 00-312 Warszawa \\ Poland \\ a.guziak@uw.edu.pl
}

